\title{
PENERAPAN MODEL PEMBELAJARAN \\ PROBLEM BASED LEARNING DENGAN MEDIA KOMAT TERHADAP PEMECAHAN MASALAH DAN KECEMASAN MATEMATIKA SISWA
}

\section{IMPLEMENTATION OF PROBLEM BASED LEARNING MODEL WITH KOMAT MEDIA ON PROBLEM SOLVING AND MATH ANXIETY OF STUDENTS}

\author{
Ira Purwandari ${ }^{1^{*}}$, Wiwik Ekawati ${ }^{2}$, Lia Budi Tristanti ${ }^{3}$ \\ ${ }^{1}$ Pendidikan Matematika, MAN 4 Jombang, Jl. K.H Bisri Syansuri No 21 Denanyar Jombang, \\ Kecamatan Jombang, Kabupaten Jombang, 61416, Indonesia \\ 2Pendidikan Matematika, MTsN 4 Jombang Jl. K.H Bisri Syansuri No 77 Denanyar Jombang, \\ Kecamatan Jombang, Kabupaten Jombang, 61418, Indonesia \\ 3Pendidikan Matematika, Program Magister, STKIP PGRI Jombang, Jl. Pattimura III / 20 \\ Sengon, Kecamatan Jombang, Kabupaten Jombang, 61418, Indonesia \\ *irapurwandari1@gmail.com \\ Hp: 085746499605
}

\section{ABSTRAK}

Setiap siswa memiliki karakteristik yang berbeda sehingga sekalipun dia menerima pelayanan pendidikan yang sama pasti masih terdapat siswa yang mengalami kesulitan belajar. Salah satu ciri orang yang mengalami kesulitan belajar adalah memiliki rasa cemas atau gelisah ketika belajar (math anxiety). Kecemasan belajar memiliki dampak yang negative terhadap prestasi belajar. Tujuan penelitian ini adalah mendeskripsikan ada atau tidak ada perbedaan kemampuan memecahkan masalah dan kecemasan siswa dalam pembelajaran Based Learning dengan media KOMAT. Jenis penelitian ini adalah penelitian eksperiemen, dengan jenis data kuantitatif. Sedangkan desain yang digunakan dalam penelitian ini adalah quasi experimental design, dengan rancangan penelitian menggunakan One Groups Pretest-Posttest Design, yaitu desain penelitian yang terdapat pretest sebelum diberi perlakuan Problem Based Learning (PBL) dan posttest setelah diberi perlakuan PBL. Subjek penelitian ini adalah siswa kelas X dengan jumlah 34 siswa. Metode pengumpulan data menggunakan metode tes. Instrumen penelitian menggunakan lembar tes. Teknik analisis data hasil tes menggunakan uji statistik. Berdasarkan hasil output pada perhitungan uji t menunjukkan nilai Sig. (2-tailed) $=0,00<0.05$, maka $\mathrm{H}_{0}$ ditolak. Sehingga dapat disimpulkan bahwa terdapat perbedaan dalam menerapkan model Problem Based Learning (PBL) dengan media KOMAT terhadap kemampuan menyelesaikan masalah matematika siswa MAN 4 Jombang. Berdasarkan hasil output pada perhitungan uji t menunjukkan nilai Sig. (2-tailed) $=0,000<0.05$, maka $\mathrm{H}_{0}$ diterima. Sehingga dapat disimpulkan bahwa tidak terdapat perbedaan dalam menerapkan model Problem Based Learning (PBL) dengan media KOMAT terhadap kecemasan matematika siswa MAN 4 Jombang.

Kata kunci: problem based learning, KOMAT, pemecahan masalah, kecemasan siswa 
Jurnal THEOREMS (The Original Research of Mathematics) Vol. 5 No. 1, Juli. hal. 1-12

URL: http://jurnal.unma.ac.id/index.php/th

Naskah masuk:2020-01-19 Naskah diperbaiki:2020-04-09 Naskah diterima: 2020-07-13

\section{ABSTRACT}

Each student has different characteristics so that even if he receives the same educational service there must be students who have learning difficulties. One of the characteristics of people who have learning difficulties is having anxiety or anxiety when learning (math anxiety). Learning anxiety has a negative impact on learning achievement. The purpose of this study is to describe whether or not there are differences in the ability to solve problems and student anxiety in learning based learning with KOMAT media. This type of research is experimental research, with quantitative data types. While the design used in this study is a quasi experimental design, with a research design using One Groups Pretest-Posttest Design, namely research designs that have pretests before being given Problem Based Learning (PBL) and posttest after being given PBL treatment. The subjects of this study were class $X$ students with a total of 34 students. The data collection method uses the test method. The research instrument uses a test sheet. The technique of analyzing test result data uses statistical tests. Based on the results of the output in the $t$ test calculation shows the Sig. (2-tailed) $=0.00<0.05$, then H0 is rejected. So it can be concluded that there are differences in applying the Problem Based Learning (PBL) model with KOMAT media on the ability to solve mathematical problems of MAN 4 Jombang students. Based on the results of the output in the $t$ test calculation shows the Sig. (2-tailed) $=0.00<0.05$, then H0 is accepted. So it can be concluded that there is no difference in applying the Problem Based Learning (PBL) model with KOMAT media to the mathematics anxiety of MAN 4 Jombang students.

Kata kunci: problem based learning, KOMAT, problem solving, math anxiety 


\section{PENDAHULUAN}

Pendidikan adalah proses untuk mengubah tingkah laku siswa menjadi lebih dewasa dan mandiri. Lingkungan sekitar juga berpengaruh pada tingkah laku siswa. Salah satu mata pelajaran yang ada di sekolah adalah matematika. Tujuan kurikulum 2013 pembelajaran matematika di SMA mencakup empat kompetensi, yaitu kompetensi sikap spiritual, sikap sosial, pengetahuan, dan keterampilan.

Rumusan

Pengetahuan yaitu memahami, menerapkan, menganalisis pengetahuan faktual, konseptual, procedural (Permendikbud No 23 Tahun 2018), hal tersebut menjelaskan bahwa pemecahan masalah merupakan salah satu tujuan pembelajaran yang harus dicapai. Selain itu, tujuan pembelajaran matematika menurut National Council of Teachers of Mathematics (NCTM, 2000) menekankan pada kemampuan siswa dalam pemecahan masalah. Ketika menyelesaikan suatu masalah, siswa harus memiliki kemampuan argumen (Tristanti, Sutawidjaja, As'ari, Muksar, 2015, 2016, 2017). Hal tersebut sesuai dengan Tristanti (2019) bahwa argumen digunakan untuk menentukan, menghasilkan dan mendukung solusi yang masuk akal.

Matematika masih dianggap pelajaran yang sulit bagi kebanyakan siswa. Sesuai dengan pendapat Cockroft (1982: 68) bahwa "Mathematics is a difficult subject both to teach and to learn" yang artinya matematika adalah pelajaran yang sulit baik untuk mengajar dan belajar. Salah satu penyebab kesulitan siswa adalah siswa tidak bisa menyelesaikan masalah matematika. Kesulitan siswa dalam menyelesaikan masalah matematika juga dialami oleh siswa MAN 4 Denanyar Jombang. Hal tersebut nampak dari hasil pretest yang diberikan ke 34 siswa. Banyak siswa yang menjawab dengan benar ada 9 siswa, yang mengerjakan sesuai prosedur tetapi jawaban salah ada 16 siswa, dan yang hanya menuliskan informasi yang di soal ada 9 siswa.

Berdasarkan hal tersebut nampak bahwa siswa belum bisa memisahkan situasi dalam soal ke simbol matematika, siswa berhenti pada model matematika dan belum mempunyai perencanaan dalam menyelesaikan matematika. sehingga siswa dalam menjawab menggunakan estimasi yaitu harga buku Rp 6.000, harga sebuah pensil Rp 3.000 dan harga sebuah penggaris Rp 4.000 . Berdasarkan data diatas nampak bahwa kemampuan siswa dalam pemecahan masalah masih perlu diperhatikan dalam proses pembelajaran matematika.

Umumnya siswa MAN 4 Jombang berada pada usia remaja, dimana terjadi proses perubahan psikologi dan pembentukan kepribadian sehingga rentan dengan tingginya tingkat kecemasan. Kecemasan merupakan suatu kondisi diri yang tidak menyenangkan meliputi rasa takut, rasa tegang, khawatir, bingung, tidak suka yang sifatnya subjektif dan timbul karena adanya perasaan tidak aman terhadap bahaya yang diduga akan terjadi (Nawangsari, 2001). Sedangkan kecemasan matematika merupakan bentuk perasaan seseorang baik berupa perasaan takut, tegang ataupun cemas dalam menghadapi persoalan matematika atau dalam melaksanakan pembelajaran matematika dengan berbagai bentuk 
gejala yang ditimbulkan (Wicaksono, dan Saufi, 2013).

Penyebab utama kecemasan siswa adalah otoritas guru (Skemp, 1971: 129-131). Sedangkan penyebab ketakutan anak terhadap matematika diantaranya: pertama, matematika sebagai mata pelajaran yang diajarkan di sekolah merupakan cabang ilmu yang spesifik. Objek matematika adalah fakta, proses, prinsip, dan konsep yang semuanya berperan dalam proses berpikir matematis dengan salah satu cirinya yaitu adanya penalaran yang logis. Hal ini menyebabkan anak hanya berorientasi pada hasil dan nilai saja bukan proses pembelajaran itu sendiri. Ketika seorang anak mendapat nilai yang jelek, dia menjadi tertekan dan menganggap dirinya bodoh (Wicaksono dan Saufi, 2013).

Kecemasan siswa pada matematika juga dialami oleh kelas $X$ MIA 1 MAN 4 Jombang. Banyak siswa yang takut ketika pergi ke kelas matematika yaitu 3, banyak siswa yang gelisah saat pergi ke papan tulis di kelas matematika yaitu 2, banyak siswa takut untuk bertanya di kelas matematika yaitu 3, banyak siswa yang selalu khawatir saat dipanggil di kelas matematika yaitu 3,banyak siswa mengerti matematika sekarang, khawatir bahwa itu akan segara menjadi sangat sulit yaitu 7 , banyak siswa yang cenderung untuk keluar dari zona kelas matematika yaitu 2, banyak siswa yang takut tes matematika lebih dari jenis lain yaitu 2, banyak siswa yang tidak tahu bagaimana belajar untuk tes matematika yaitu 3, banyak siswa yang merasa di kelas matematika, tetapi ketika pulang rasanya tidak pernah ada yaitu 6, banyak siswa yang takut tidak akan dapat bersaing dengan seluruh kelas yaitu 3 .

Berdasarkan uraian diatas ditemukan masalah yaitu:

1. kurangnya tingkat penguasaan konsep siswa yang disebabkan proses pembelajaran yang tidak berorientasi pada masalah,

2. rendanya kemampuan siswa dalam menyelesaikan masalah matematika,

3. banyak siswa yang cemas dalam mempelajari matematika.

Sehingga diperlukan suatu model pembelajaran berbasis masalah yang menfasilitasi siswa menjadi pembelajaran yang aktif dalam menyelesaikan masalah.

Model pembelajaran yang dapat diterapkan adalah pembelajaran berbasis masalah yaitu Problem based Learning (PBL). Model ini diharapkan dapat membantu siswa menjadi lebih faham, mendorong untuk mampu memecahkan masalah, dan dapat memotivasi siswa dalam belajar. Hal tersebut didasarkan pada Shoimin (2014) bahwa pembelajaran Problem Based Learning (PBL) dapat melatih kemampuan memecahkan suatu masalah pada kehidupan nyata. Selain itu, Model Problem Based Learning (PBL) dapat mengembangkan pemikiran kritis dan kreatif peserta didik (Kurniasih \& Sani, 2016: 49).

PBL banyak digunakan dalam penelitian diantaranya Baden \& Major (2004). Hasil penelitian Baden \& Major (2004) bahwa siswa dalam kelompok diskusi dengan PBL memiliki motivasi yang lebih tinggi, peningkatan kemampuan menyelesaikan masalah (problem solving) dan keterampilan belajar mandiri dibandingkan dengan siswa 
pada pembelajaran tradisional. Sujatmika (2016) juga menunjukkan bahwa PBL lebih efektif dari model pembelajaran konvensional. Hasil penelitian Tristanti (2017) juga menyatakan bahwa ada pengaruh PBL terhadap pemahaman siswa.

Media KOMAT (Koper Matematika) merupakan media yang terbentuk untuk memotivasi siswa menjadi lebih aktif dalam memecahkan masalah. Dengan media KOMAT ini, diharapkan siswa tidak lagi cemas dalam mempebelajari matematika. Media KOMAT terdiri dari kartu soal yang membentuk suatu gambar Logo MAN 4 Jombang. Kelompok yang mendapat bintang terbanyak akan mendapat reward.

Matematika dengan Soal yang belum terjawab. Berikut gambar media KOMAT

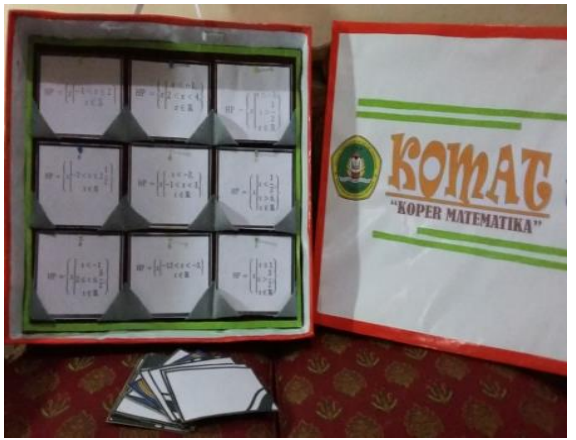

Gambar 1

Koper Matematika Nampak Dalam

Setiap siswa memiliki karakteristik yang berbeda sehingga sekalipun dia menerima pelayanan Pendidikan yang sama pasti masih terdapat siswa yang mengalami kesulitan belajar. Salah satu ciri orang yang mengalami kesulitan belajar adalah memiliki rasa cemas atau gelisah ketika belajar (math anxiety). Kecemasan belajar memiliki dampak yang negative terhadap prestasi belajar (Ramirez dkk, 2013).
Berdasarkan uraian di atas, tujuan penelitian ini adalah mendeskripsikan ada atau tidak ada perbedaan kemampuan memecahkan masalah dan kecemasan siswa dalam pembelajaran Based Learning dengan media KOMAT. Berikut langkahlangkah model pembelajaran Based Learning

Fase 1. Orientasi peserta didik kepada masalah

Peserta didik mengamati masalah kontekstual yang diberikan oleh guru terkait System Persamaan Linear Tiga Variabel

Fase 2. Mengorganisasikan peserta didik)

Peserta didik melakukan diskusi kelompok terkait masalah kontekstual sistem persamaan linear tiga variable Fase 3. Membimbing penyelidikan individu dan kelompok

1. Membantu peserta didik mendefinisikan dan mengorganisasikan tugas belajar yang berhubungan dengan masalah tersebut.

2. Mendorong peserta didik untuk mengumpulkan informasi yang sesuai untuk memecahkan permasalahan yang diberikan

3. Memberikan bantuan berupa penggalian informasi yang diperlukan atau yang terdapat dalam masalah tersebut.

4. Informasi-informasi yang diharapkan ditemukan oleh peserta didik seperti variabelvariabel yang terdapat pada masalah tersebut

Fase 4. Mengembangkan dan menyajikan hasil karya

Membantu peserta didik dalam merencanakan dan menyiapkan hasil diskusi/penyelidikan berupa model matematika yaitu sistem persamaan linear tiga variabel serta penyelesaian dari masalah tersebut 
Fase 5. Menganalisa dan mengevaluasi proses pemecahan masalah

1. Mengevaluasi hasil penyelidikan peserta didik dengan diskusi klasikal untuk diberikan masukan oleh seluruh kelas

2. Menyimpulkan hasil diskusi terkait sistem persamaan linear tiga variable

\section{METODE PENELITIAN}

Jenis penelitian ini adalah penelitian eksperiemen, dengan jenis data kuantitatif. Sedangkan desain yang digunakan dalam penelitian ini adalah quasi experimental design, dengan rancangan penelitian menggunakan One Groups Pretest-Posttest Design, yaitu desain penelitian yang terdapat pretest sebelum diberi perlakuan Problem Based Learning (PBL) dan posttest setelah diberi perlakuan PBL. Design penelitian ini dapat digambarkan seperti Gambar 4 berikut:

$$
\begin{array}{ccc}
\mathrm{O}_{1} & \mathrm{X} & \mathrm{O}_{2} \\
& \text { Gambar } & \mathbf{4} \\
\text { Desain } & \text { Penelitian }
\end{array}
$$

Ket: $\mathrm{O}_{1}$ merupakan pre test

$X$ merupakan treatment terhadap pembelajaran dengan PBL dan media KOMAT

$\mathrm{O}_{2}$ merupakan post test

Populasi dalam penelitian ini adalah seluruh siswa kelas X MAN 4 Jombang yang berjumlah 450 siswa. Teknik pengambilan sampel yang digunakan dalam penelitian ini yaitu propusive sampling. Sampel penelitian ini adalah siswa kelas X MIA 1 karena siswa mengalami masalah dalam pemecahan masalah dan memiliki tingkat kecemasan yang tinggi.

Instrumen penelitian yang digunakan untuk pengambilan data dalam penelitian ini yaitu tes dan angket.

Tes
Tes digunakan untuk mengumpulkan data kemampuan menyelesaian masalah matematika. Kriteria penskoran berdasarkan indikator kemampuan menyelesaian masalah matematika yang disajikan dalam Tabel 1 .

\begin{tabular}{|c|c|c|}
\hline $\begin{array}{c}\text { Tahap } \\
\text { Menyelesaikan } \\
\text { Masalah }\end{array}$ & Indikator & Skor \\
\hline \multirow[t]{3}{*}{$\begin{array}{l}\text { 1. Memahami } \\
\text { Masalah }\end{array}$} & $\begin{array}{l}\text { 1.1. Menuliskan } \\
\text { yang } \\
\text { diketahui }\end{array}$ & $\begin{array}{l}4=\text { menuliskan yang diketahui dengan benar } \\
2=\text { menuliskan yang diketahui dengan tidak } \\
\quad \text { benar } \\
0=\text { tidak menuliskan yang diketahui }\end{array}$ \\
\hline & $\begin{array}{l}\text { 1.2. Menuliskan } \\
\text { yang } \\
\text { ditanya }\end{array}$ & $\begin{array}{l}4=\text { menuliskan yang ditanya dengan benar } \\
2=\text { menuliskan yang ditanya dengan tidak benar } \\
0=\text { tidak menuliskan yang ditanya }\end{array}$ \\
\hline & $\begin{array}{l}\text { 1.3. } \text { Membuat } \\
\text { model } \\
\text { matematika }\end{array}$ & $\begin{array}{l}4=\text { Membuat model matematika dengan benar } \\
2=\text { Membuat model matematika dengan tidak } \\
\quad \text { benar } \\
0=\text { tidak membuat model matematika }\end{array}$ \\
\hline $\begin{array}{l}\text { 2. Memilih } \\
\text { strategi yang }\end{array}$ & $\begin{array}{l}\text { 2.1. Memilih } \\
\text { alternatif }\end{array}$ & $\begin{array}{l}4=\text { Memilih alternatif jawaban yang tepat } \\
2=\text { Memilih alternatif jawaban tidak tepat }\end{array}$ \\
\hline
\end{tabular}

Tabel 1

Tahap, Indikator dan Pedoman Penyekoran Kemampuan Menyelesaikan Masalah

Copyright $(2020$, Jurnal THEOREMS (The Original Research of Mathematics) p-ISSN: 2528-102X, e-ISSN: 2541-4321, URL: http://jurnal.unma.ac.id/index.php/th 
Jurnal THEOREMS (The Original Research of Mathematics) Vol. 5 No. 1, Juli. hal. 1-12

URL: http://jurnal.unma.ac.id/index.php/th

Naskah masuk:2020-01-19 Naskah diperbaiki:2020-04-09 Naskah diterima: 2020-07-13

\begin{tabular}{|c|c|c|}
\hline $\begin{array}{l}\text { tepat untuk } \\
\text { menyelesaik } \\
\text { an masalah }\end{array}$ & $\begin{array}{l}\text { jawaban } \\
\text { yang tepat }\end{array}$ & $0=$ Tidak Memilih alternatif jawaban yang tepat \\
\hline \multirow[t]{2}{*}{$\begin{array}{l}\text { 3. Menyelesaik } \\
\text { an masalah } \\
\text { dengan } \\
\text { benar dan } \\
\text { sistematis }\end{array}$} & $\begin{array}{l}\text { 3.1. Menyelesai } \\
\text { kan } \\
\text { masalah } \\
\text { dengan } \\
\text { benar dan } \\
\text { sistematis }\end{array}$ & $\begin{array}{l}4=\text { Menyelesai kan masalah dengan benar dan } \\
\text { sistematis } \\
2=\text { Menyelesai kan masalah tidak benar dan } \\
\text { tidak sistematis } \\
0=\text { Tidak menyelesaikan masalah dengan benar } \\
\text { dan sistematis }\end{array}$ \\
\hline & $\begin{array}{l}\text { 3.2. Menuliskan } \\
\text { kesimpulan }\end{array}$ & $\begin{array}{l}4=\text { Menuliskan kesimpulan dengan benar } \\
2 \text { = Menuliskan kesimpulan tidak benar } \\
0=\text { tidak menuliskan kesimpulan }\end{array}$ \\
\hline
\end{tabular}

Skor kemampuan menyelesaian masalah matematika dikonversi ke nilai 0-100 menggunakan rumus berikut:

Nilai kemampuan menyelesaian masalah

$$
=\frac{\text { Skor yang didapat }}{\text { skor maksimum }} \times 100
$$

b. Angket

Angket untuk mengumpulkan data kecemasan siswa pada pembelajaran matematika. Angket ini menggunakan penilaian sekala likert dengan 5 pilihan jawaban. Kriteria penskoran setiap butir pernyataan positif dan negatif disajikan dalam Tabel 2.

Tabel 2

Pensekoran Hasil Angket

\begin{tabular}{|l|c|c|}
\hline \multirow{2}{*}{ Pilihan Jawaban } & \multicolumn{2}{|c|}{ Butir } \\
\cline { 2 - 3 } & Positif & Negatif \\
\hline Sangat setuju & 5 & 1 \\
\hline Setuju & 4 & 2 \\
\hline Biasa saja & 3 & 3 \\
\hline Tidak setuju & 2 & 4 \\
\hline $\begin{array}{l}\text { Sangat tidak } \\
\text { setuju }\end{array}$ & 1 & 5 \\
\hline
\end{tabular}

Angket kecemasam dikembangkan berdasarkan Teori Freedman (2012).

Berikut indikator siswa mengalami kecemasan matematika:

1. takut pada matematika;
2. menganggap matematika itu menyulitkan (selalu berprasangka negatif);

3. tegang saat belajar matematika;

4. takut tidak bisa mengerjakan soal matematika;

5. takut dan malu tidak bisa menjawab pertanyaan guru saat belajar matematika;

6. tidak percaya diri saat belajar matematika;

7. sering lupa terhadap konsep matematika.

Angket kecemasan siswa pada pembelajaran matematika teridiri dari 15 butir pernyataan dengan penilaian skala likert dengan 5 pilihan jawaban, sehingga data memiliki skor maksimum ideal 75 dan skor minimum ideal 15.

Data kemampuan menyelesaian masalah matematika dan kecemasan siswa pada pembelajaran matematika dianalisis dengan menggunakan statistik parametrik yaitu t-test. Namun sebelumnya dilakukan Uji Prasyarat Analisisa yaitu Uji Normalitas dan homonenitas. 
Jurnal THEOREMS (The Original Research of Mathematics) Vol. 5 No. 1, Juli. hal. 1-12

URL: http://jurnal.unma.ac.id/index.php/th

Naskah masuk:2020-01-19 Naskah diperbaiki:2020-04-09 Naskah diterima: 2020-07-13

\section{HASIL PENELITIAN DAN PEMBAHASAN}

1. Kemampuan Pemecahan Masalah

a. Normalitas

Berikut hasil uji normalitas data pretest dan posttest menggunakan Shapiro-Wilk:

Tabel 3

Hasil Uji Normalitas

\begin{tabular}{|c|c|r|r|r|}
\hline \multicolumn{2}{|c|}{ Kelompok } & \multicolumn{3}{|c|}{ Shapiro-Wilk } \\
\cline { 2 - 5 } & Statistic & df & Sig. \\
\hline $\begin{array}{c}\text { Nilai_ke } \\
\text { mampuan } \\
\text { _pemecah }\end{array}$ & Pretest & .955 & 34 & .175 \\
$\begin{array}{c}\text { an_masal } \\
\text { ah }\end{array}$ & $\begin{array}{c}\text { Posttes } \\
\mathrm{t}\end{array}$ & .939 & 34 & .057 \\
\hline
\end{tabular}

Berdasarkan hasil output uji normalitas pada tabel di atas menunjukkan bahwa nilai Asymp. Sig. pretest sebesar 0,175, maka nilai Asymp. Sig. pretest > 0,05, sehingga data pretest berdistribusi normal. Sedangkan nilai Asymp. Sig. postest sebesar 0,057, maka nilai Asymp. Sig. posttest $>0,05$, sehingga data posttest juga berdistribusi normal.

b. Homogenitas

Berikut hasil uji homogenitas data nilai kemampuan pemecahan masalah matematika siswa

\section{Tabel 4}

Hasil Uji Homogenitas

\begin{tabular}{|r|r|r|r|}
\hline $\begin{array}{c}\text { Levene } \\
\text { Statistic }\end{array}$ & df1 & df2 & Sig. \\
\hline .163 & 1 & 66 & .688 \\
\hline
\end{tabular}

Berdasarkan hasil output uji homogenitas pretest dan posttest pada tabel di atas menunjukkan bahwa nilai Sig. sebesar 0,688, maka nilai Sig. > 0,05, sehingga data pretest dan posttest homogen

c. Uji t

Berikut data hasil perhitungan uji statistik menggunakan uji t:

Berdasarkan Tabel 6 hasil output pada perhitungan uji $t$ menunjukkan nilai Sig. (2-tailed) $=0,00<0.05$, maka $\mathrm{H}_{0}$ ditolak. Sehingga dapat disimpulkan bahwa terdapat perbedaan dalam menerapkan model Problem Based Learning (PBL) dengan media KOMAT terhadap kemampuan menyelesaikan masalah matematika siswa MAN 4 Jombang.

Berdasarkan Tabel 6 hasil output pada perhitungan uji $t$ menunjukkan nilai Sig. (2-tailed) $=0,00<0.05$, maka $\mathrm{H}_{0}$ ditolak. Sehingga dapat disimpulkan bahwa terdapat perbedaan dalam menerapkan model Problem Based Learning (PBL) dengan media KOMAT terhadap kemampuan menyelesaikan masalah matematika siswa MAN 4 Jombang.

Berikut deskripsi kemampuan menyelesaikan masalah berdasarkan salah satu jawaban siswa:

1. Memahami masalah

Berdasarkan hasil pretest dan posttest siswa yang memahami masalah dengan menuliskan apa yang diketahui dan apa yang ditanya dengan benar dan membuat model matematika berturut-turut sebanyak 9 orang siswa dan 22 orang siswa. Sebanyak 16 orang siswa dan 4 orang siswa menjawab sesuai prosedur tetapi jawaban salah sedangkan yang hanya menuliskan informasi disoal ada 9 siswa dan 8 siswa

2. Memilih strategi yang tepat untuk menyelesaikan masalah

Berdasarkan hasil pretest dan posttest siswa sebanyak 9 orang siswa dan 22 orang siswa yang memilih alternatif jawaban yang tepat

3. Menyelesaikan masalah dengan benar dan sistematis

Berdasarkan hasil pretest dan posttest siswa sebanyak 5 orang

Copyright $\bigcirc 2020$, Jurnal THEOREMS (The Original Research of Mathematics) p-ISSN: 2528-102X, e-ISSN: 2541-4321, URL: http://jurnal.unma.ac.id/index.php/th 
Jurnal THEOREMS (The Original Research of Mathematics) Vol. 5 No. 1, Juli. hal. 1-12

URL: http://jurnal.unma.ac.id/index.php/th

Naskah masuk:2020-01-19 Naskah diperbaiki:2020-04-09 Naskah diterima: 2020-07-13

siswa dan 17 orang siswa menyelesaikan masalah dengan benar dan sistematis, dan sebanyak 3 orang siswa dan 10 orang siswa yang menuliskan kesimpulan

Berikut hasil posttest siswa MDA yang memenuhi indicator pemecahan masalah. :

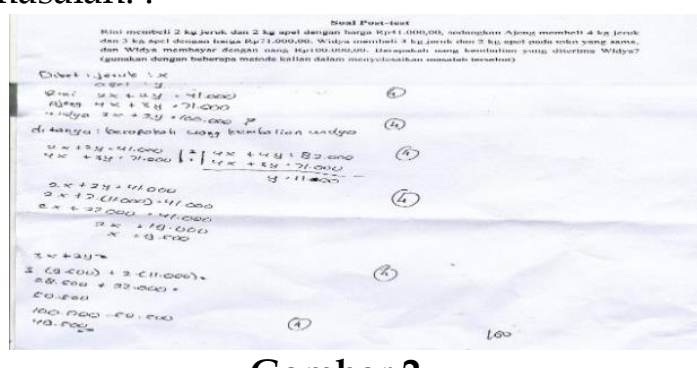

Gambar 2

\section{Hasil Jawaban MDA}

Berdasarkan lembar jawaban posttest siswa di atas dapat diketahui bahwa MDA telah memahami masalah yang diberikan, hal ini terlihat pada hasil jawaban siswa MDA. Ini merupakan bagian daripada menuliskan apa yang diketahui yaitu jeruk yang dimisalkan dengan $x$ dan apel yang dimisalkan dengan $y$. siswa MDA menuliskan apa yang ditanyakan yaitu berapakah uang kembalian widya?. Siswa MDA menuliskan model matematika dalam memahami masalah yang diberikan yaitu Rini $2 x+2 y=41.000$ Ajeng $4 x+3 y=71.000$ Widya $3 x+2 y=$ 100.000 . Siswa dapat memilih strategi yang tepat dalam menyelesaikan masalah yaitu eliminasi. MDA melakukan pengecekan kembali terhadap semua langkah yang telah dikerjakan, hal ini terlihat siswa menuliskan kesimpulan dari jawaban yang telah ia peroleh.

\section{Kecemasan Matematika}

a. Normalitas

Berdasarkan hasil output uji normalitas menggunakan ShapiroWilk menunjukkan bahwa nilai
Asymp. Sig. pretest sebesar 0,200, maka nilai Asymp. Sig. pretest > 0,05 , sehingga data pretest berdistribusi normal. Sedangkan nilai Asymp. Sig. postest sebesar 0,075, maka nilai Asymp. Sig. posttest > 0,05, sehingga data posttest juga berdistribusi normal.

b. Homogenitas

Berikut hasil uji Homogenitas Kecemasan Matematika Siswa

Tabel 6

Hasil Tes Homogenitas Kecemasan Matematika

\begin{tabular}{|r|r|r|c|}
\hline Levene Statistic & df1 & df2 & Sig. \\
\hline 3.014 & 1 & 66 & .087 \\
\hline
\end{tabular}

Berdasarkan hasil output uji homogenitas data pretest dan posttest pada tabel di atas menunjukkan bahwa nilai Sig. sebesar 0,087, maka nilai Sig. > 0,05 , sehingga varian data kecemasan matematika siswa saat pretest dan posttest adalah sama atau homogeny.

c. Ujit

Tabel 7 merupakan hasil perhitungan uji statistik menggunakan uji t.

Berdasarkan hasil output pada perhitungan uji $\mathrm{t}$ menunjukkan nilai Sig. (2-tailed) $=0,000<0.05$, maka $\mathrm{H}_{0}$ ditolak. Sehingga dapat disimpulkan bahwa terdapat perbedaan dalam menerapkan model Problem Based Learning (PBL) dengan media KOMAT terhadap kecemasan matematika siswa MAN 4 Jombang

Hasil penelitian ini menunjukkan bahwa terdapat perbedaan dalam menerapkan model Problem Based Learning (PBL) dengan media KOMAT terhadap kemampuan menyelesaikan masalah matematika dan kecemasan 
matematika siswa. Sehingga model Problem Based Learning (PBL) dengan media KOMAT efektif untuk meningkatkan kemampuan menyelesaikan masalah matematika siswa. Hal tersebut sesuai dengan Tristanti (2017), dalam PBL siswa dilatih untuk memecahkan masalah yang mereka hadapi dalam situasi nyata, misalnya dalam bentuk simulasi dan masalah yang memang ada di dunia nyata. Hasil penelitian yang serupa oleh Ge, Planas, Er (2010), bahwa penalaran dan kemampuan pemecahan masalah siswa meningkat dengan PBL.

Problem Based Learning (PBL) membantu siswa dalam mengembangkan kemampuan analisis yang meliputi mendefinisikan dan menyelesaikan masalah Problem Based Learning (PBL) juga mengembangkan kemampuan siswa dalam mengambil keputusan saat menyelesaikan masalah (Tosun dan Taskesenligil, 2011). Hasil penelitian ini memperkuat hasil penelitian Ajai, Imoko, \& $\mathrm{O}^{\prime} \mathrm{kwu}$, (2013), Ali, Hukamdad, Akhter dan Khan (2010) dari Pakistan, Loggerenberg-Hattingh (2003) dari Afrika Selatan serta Raimi dan Adeoye (2004) di Nigeria, yang semuanya membuktikan bahwa kinerja siswa pada pembelajaran Problem Based Learning (PBL) berkinerja lebih baik daripada siswa kelompok konvensional. Namun bertentangan dengan Visser (2002) yang menemukan bahwa siswa dalam kelompok LectureBased Group memiliki kinerja yang jauh lebih baik daripada kelompok PBL.

\section{KESIMPULAN}

Berdasarkan hasil penelitian dapat disimpulkan bahwa penerapan model Problem Based Learning (PBL) dengan media KOMAT berpengaruh terhadap

menyelesaikan masalah dan kecemasan matematika siswa MAN 4 Jombang. Hasil belajar siswa juga meningkat, hal tersebut dapat dilihat pada Tabel 3. Tabel 3 menunjukkan bahwa setiap siswa mengalami peningkatan nilai kemampuan menyelesaikan masalah. Melalui pembelajaran Problem Based Learning (PBL), siswa memperoleh keterampilan memecahkan masalah yang relevan dengan kehidupan sehari-hari mereka. Penerapan model Problem Based Learning (PBL) media KOMAT berpengarih terhadap kemampuan menyelesaikan masalah dan kecemasan matematika siswa, maka hasil penelitian ini dapat dijadikan landasan untuk mengembangkan perangkat pembelajaran dengan menggunakan model Problem Based Learning (PBL), sehingga diperoleh perangkat pembelajaran yang benarbenar valid dan lebih dapat meningkatkan kemampuan menyelesaikan masalah dan kecemasan matematika siswa.

\section{SARAN}

Model pembelajaran $P B L$ dengan menggunakan media KOMAT dapat dijadikan alternatif guna meningkatkan kemampuan menyelesaikan masalah matematika siswa dengan menyesuaikan materi yang akan disampaikan. Peneliti menerapkan tiga kali pembelajaran PBL dengan media KOMAT, oleh karena itu peneliti selanjutnya disarankan untuk menerapkan pembelajaran ini minimal 3 kali agar mengurangi tingkat kecemasan matematika siswa.

\section{UCAPAN TERIMA KASIH}

Copyright (C2020, Jurnal THEOREMS (The Original Research of Mathematics) p-ISSN: 2528-102X, e-ISSN: 2541-4321, URL: http://jurnal.unma.ac.id/index.php/th 
Penulis sampaikan penghargaan yang setinggi-tingginya kepada Ibu Dr. Lia Budi Tristanti, M.Pd yang telah membimbing penulis dengan penuh kesabaran sehingga artikel ini bisa terselesaikan. Untuk temanku Aliyah, S.Pd yang telah meluangkan waktunya untuk membantu sehingga artikel ini bisa terselesaikan. Untuk anak - anakku $X$ MIA-1 yang hebat, terima kasih atas partisipasinya, hanya Allah yang bisa membalas

\section{DAFTAR PUSTAKA}

[1] Permendikbud No 23 Tahun 2018 Tentang Perubahan Atas Peraturan Menteri Pendidikan Dan Kebudayaan Nomor 24 Tahun 2016 Tentang Kompetensi Inti Dan Kompetensi Dasar Pelajaran Pada Kurikulum 2013 Pada Pendidikan Dasar Dan Pendidikan Menengah

[2] NCTM. (2000). Principles and Standards of School Mathematics. Reston, VA: Author.

[3] Tristanti, L. B., Sutawidjaja, A., As' ari, A. R., \& Muskar, M. (2016). The Construction of Deductive Warrant Derived from Inductive Warrant in Preservice-Teacher Mathematical Argumentations. Educational Research and Reviews, 11(17), 16961708.

[4] Tristanti, L. B., Sutawidjaja, A., As' ari, A. R., \& Muskar, M. (2017). Types of Warrant in Mathematical Argumentations of ProspectiveTeacher. International Journal of Science and Engineering Investigations. Vol. 6, issue 68, September 2017, Halaman 96-101

[5] Tristanti, L. B., Sutawidjaja, A., As'ari, A. R., \& Muksar, M. (2015). Modelling Student Mathematical Argumentation with StructuralIntuitive and Deductive Warrant to
Solve Mathematics Problem. Proceeding of ICERD, 130-139.

[6] Tristanti, L. B. (2019). The process of thinking by prospective teachers of mathematics in making arguments. Journal of Education and Learning (EduLearn). Vol. 13, No. 1, February 2019, pp. 17 24

[7] Cockcroft. (1982). Mathematics counts. Tersedia di http://www.educationengland.org .uk/documents/cockcroft/cockcro ft1982.html

[8] Nawangsari, N.A.F. (2001). Pengaruh Self-Efficacydan Expectancy-Value terhadap Kecemasan Menghadapi Pelajaran Matematika.Jurnal Psikologi Pendidikan: Insan Media Psikologi, 3,2, 2001, 75-88.

[9] Wicaksono, A. B., \& Saufi, M. (2013). Mengelola kecemasan siswa dalam pembelajaran matematika. Seminar Nasional Matematika dan Pendidikan Matematika di jurusan Pendidikan Matematika FMIPA UNY, Yogyakarta (Vol. 19).

[10] Kurniasih, Imam \& Sani, Berlin. 2016. Model Pembelajaran. Yogyakarta: Kata Pena.

[11] Baden, M.S., \& Major, C.H. (2004). Foundations of Problem-based Learning. London: Open University Press.

[12] Skemp. (1971). The Psychology of Learning Mathematics.England: Penguin Books.

[13] Ramirez, G., Gunderson, E. A., Levine, S. C., \& Beilock, S. L. (2013). Math anxiety, working memory, and math achievement in early elementary school. Journal of Cognition and Development, 14(2), 187-202.

[14] Freedman, E. (2003). Do you have math anxiety? A self test. Retrieved August, 10, 2004. 
Jurnal THEOREMS (The Original Research of Mathematics) Vol. 5 No. 1, Juli. hal. 1-12

URL: http://jurnal.unma.ac.id/index.php/th

Naskah masuk:2020-01-19 Naskah diperbaiki:2020-04-09 Naskah diterima: 2020-07-13

[15] Tosun, C., dan Taskesenligil, Y. (2011). The Effect of Problem Based Learning on Student Motivation Toward Chemistry Classes and on Learning Strategies. Journal of Turkish Sciencies Education. Vol. 9, No. 1, Hal. 104-125.

[16] Ajai, J. T., Imoko, B. I., \& O'kwu, E. I. (2013). Comparison of the learning effectiveness of problembased learning (PBL) and conventional method of teaching algebra. Journal of Education and Practice, 4(1), 131-135.

[17] Ali, R., Hukamdad, Akter, A. \& Khan, A. (2010). Effect of using problem solving method in teaching mathematics on the achievement of mathematics students. Social Science, 6 (2); 6772.

[18] Logenreberg-Hattingh, V. A. (2003). Examining learning achievement and experiences of science learners in a problem-based learning environment. South African Journal of Education, 23 (1), 52-57.

[19] Raimi, S. M. \& Adeoye, F. A. (2004). Problem-based learning strategy and quantitative ability in college of education students' learning of integrated science.Ilorin Journal of Education.

[20] Visser, Y. L. (2002). Effects of problem-based and lecture-based instructional strategies on problem solving performance and learner attitudes in a high school genetics class. In Annual Meeting of the American Educational Research Association, New Orleans. 